Uluslararası Yakıtlar, Yanma ve Yangın Dergisi, 9(1), 1-8, 2021

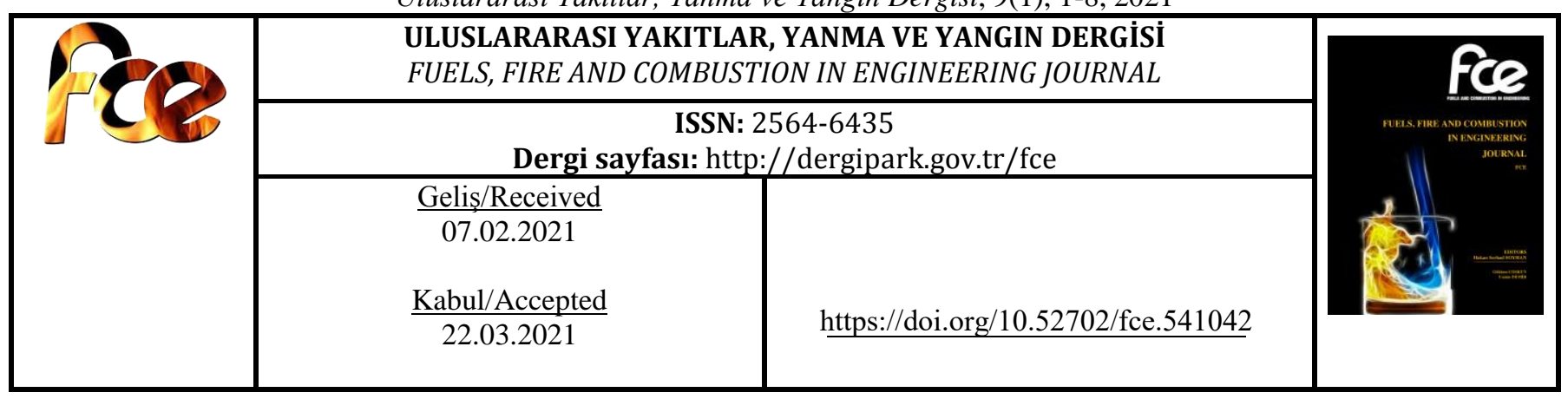

\title{
Preventing Gasoline Thermal Decomposition
}

\author{
Cemil Koyunoğlu ${ }^{1}$ \\ ${ }^{1}$ Energy Institute, Istanbul Technical University, Ayazaga Campus, 34469, Istanbul, Turkey
}

\begin{abstract}
The trouble of reducing induction system deposition has afflicted the refining market periodically given that the very early twenties when thermal breaking started to be utilized. Control of the deposit-forming properties of types of gasoline by ingredients as well as via methods techniques ended up being a crucial component of petroleum handling, and also it has played an essential function in enabling the development in fuels that have been so required for today's high-compression engines. During the period from the early twenties to the present, the problem has varied considerably in severity and in the manner in which it has been manifested. The initial surge of trouble associated with thermal cracking was eliminated first by chemical processing and finally by the use of additives. This occurrence of the problem was almost entirely attributed to preformed gums, which frequently exceeded $50 \mathrm{mg}$ per $100 \mathrm{ml}$. With the advent of catalytic cracking, stability problems were made more complex by the introduction of new types of hydrocarbons and larger quantities of nonhydrocarbon constituents, particularly of the oxygenated type frequently referred to as acid oils. These compounds gave false indications of stability in accelerated tests and for a time were considered to be beneficial as oxidation inhibitors. For this reason, the caustic treating processes used for sulfur removal were designed so that these compounds were allowed to remain in the finished gasoline. In the introduction part of the review, the issues of determining the effect of the residue in gasoline on the channels through which gasoline passes are discussed. In the second part, the effect of commercial antioxidants on the combustion stability of gasoline is examined. Determination of new methods and features related to future methods by examining the researches carried out today. The most important topic was the part where the effects of gumming on engine accents and other parts of gasoline during combustion are explained.
\end{abstract}

Keywords: Gasoline, induction system, thermal deposition, deposit-forming properties 


\section{INTRODUCTION}

Today, it has emerged that non-hydrocarbon components play an increasingly important role in the formation of unused deposits. In many instances of deposition problems, the gum contents of the gasoline were at levels which previously had been considered satisfactory, indicating either that the physical properties of the preformed gum differed from gum associated with earlier gasoline or that the nonhydrocarbon components were capable of producing depositforming constituents during their passage through the intake system [1].

The induction system of the gasoline engine includes intake manifold, the carburettor, valve stems, and intake port (see figure 1 and 2) [2]. Deposits may be formed in any of these areas. However, this paper deals only with intake valve stem or underhead deposits. These deposits are formed under the highest temperature conditions occurring in the induction system [3]. Included in this discussion is the test procedure developed for measuring induction-system deposit characteristics of fuels, and data are given from studies about the effectiveness of commercial gasoline antioxidants for intake valve deposits control.

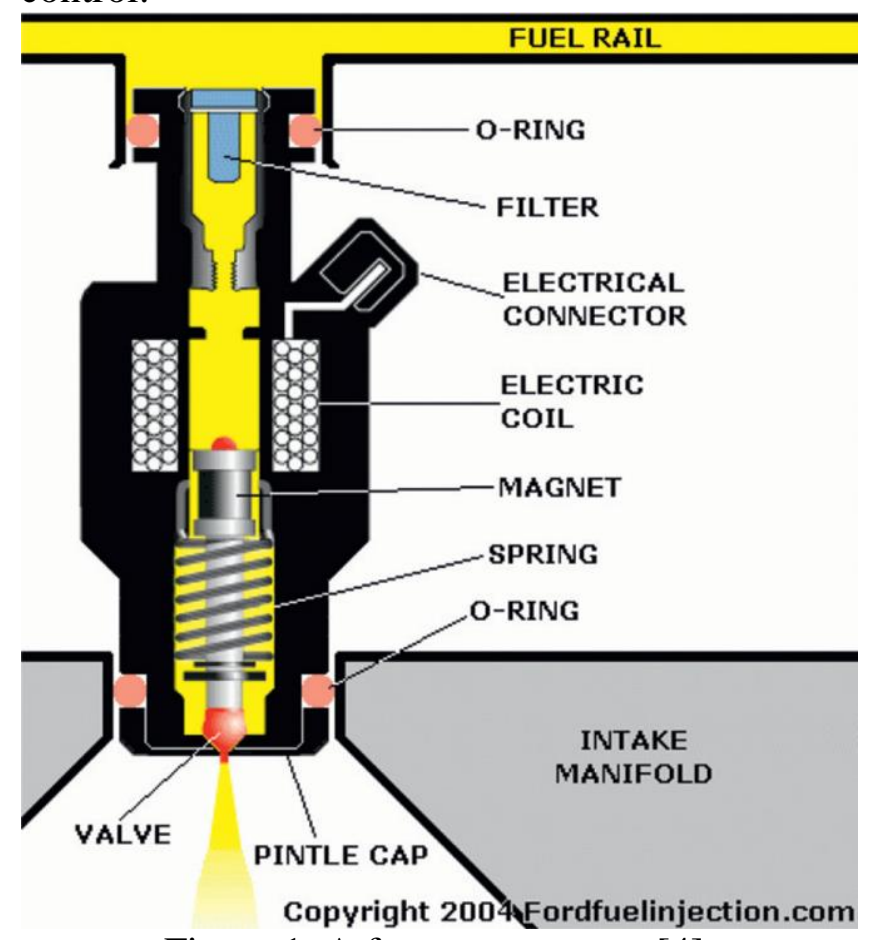

Figure 1. A few system parts [4].

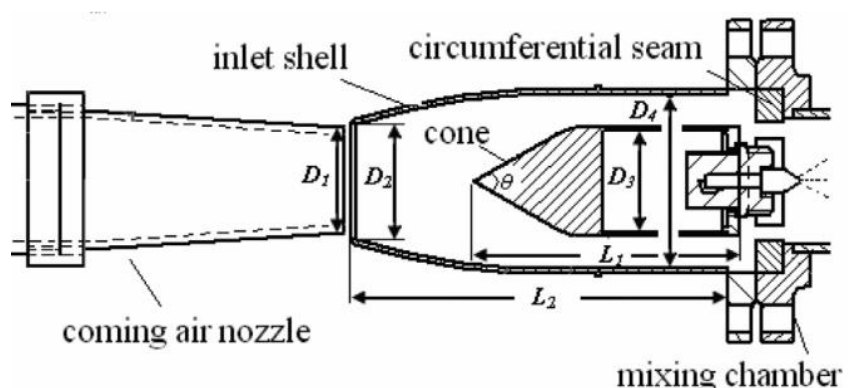

Figure 2. A simple induction system including inlet and air nozzle [5].

Intake-valve deposits may cause failure and valve sticking to seat or close properly [6]. However, before this condition is realized, deposits can reduce maximum power output [7-9]. To obtain higher horsepowers, breathing capacity has been improved in present-day cars through larger valves and ports [4]. Excessive intake valve deposits tend to defeat this design during fullthrottle operation [10]. In passenger cars, this condition is approached only during rapid acceleration and high-speed driving [11]. In heavy-duty commercial applications, however, a large portion of the operation is at full throttle (see Figure 2 and 3). Under these high-load conditions, the most severe intake-valve temperatures are attained. Under high-speed road load conditions, passenger car intake valve of underhead temperatures have been measured in the range of 500 to $600 \mathrm{~F}$ (260 to $316{ }^{\circ} \mathrm{C}$ ) [12]. But, for the same load, valve temperatures will vary considerably in the same make and model as well as with engine design $[12,13]$.

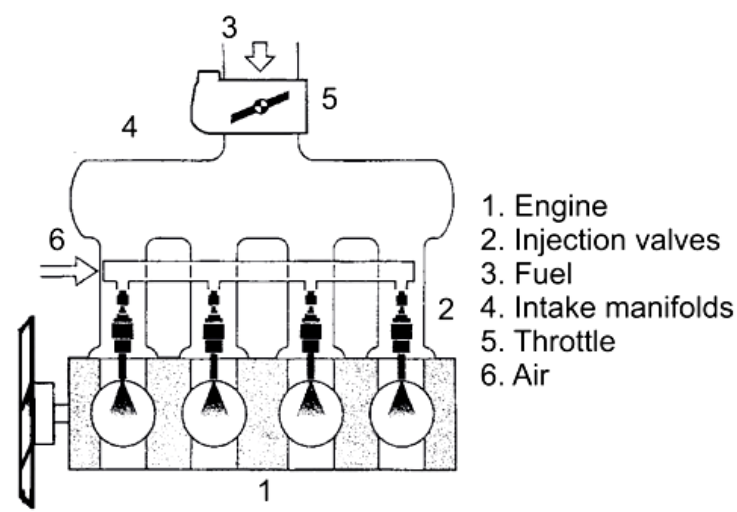

Figure 2. A simple gasoline engine system included four throttles [14]. 


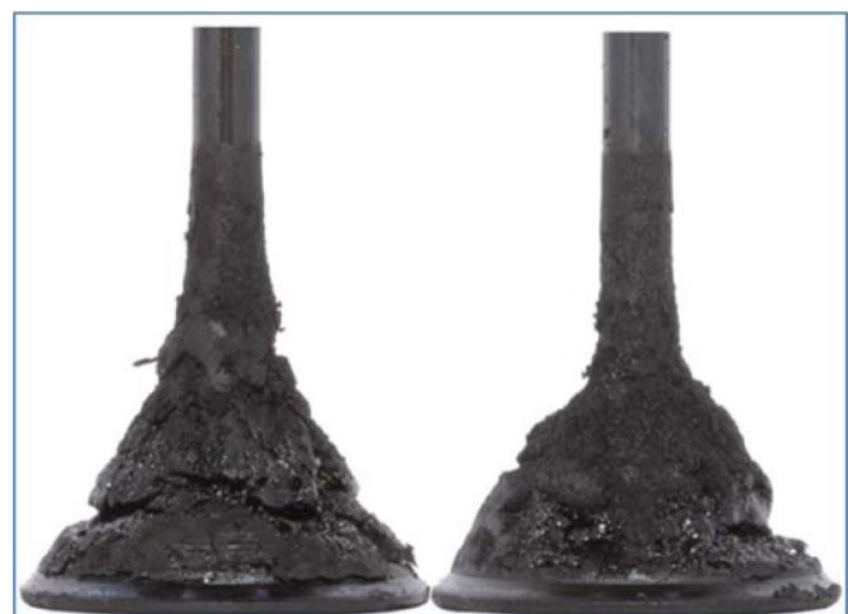

Figure 3. A ford intake valves after $190 \mathrm{~km}$ way spent [15].

\section{METHOD}

\subsection{Factors contributing to intake system deposits}

In the study and solution of a problem of this type, it is usually helpful to consider all the possible variables and attempt to place them in their proper perspective. The major factors contributing to intake deposition may be grouped into three categories (Figure 4 and 5) [6, 16]:

1. Air-borne contaminants;

(a) Exhaust and crankcase fumes [17, 18],

(b) Road dust,

2. Preformed gums;

(a) Hydrocarbons,

(b) Nonhydrocarbons,

3. Gums formed in the manifold;

(a) Liquid-phase reactions,

(b) Vapor-phase reactions,

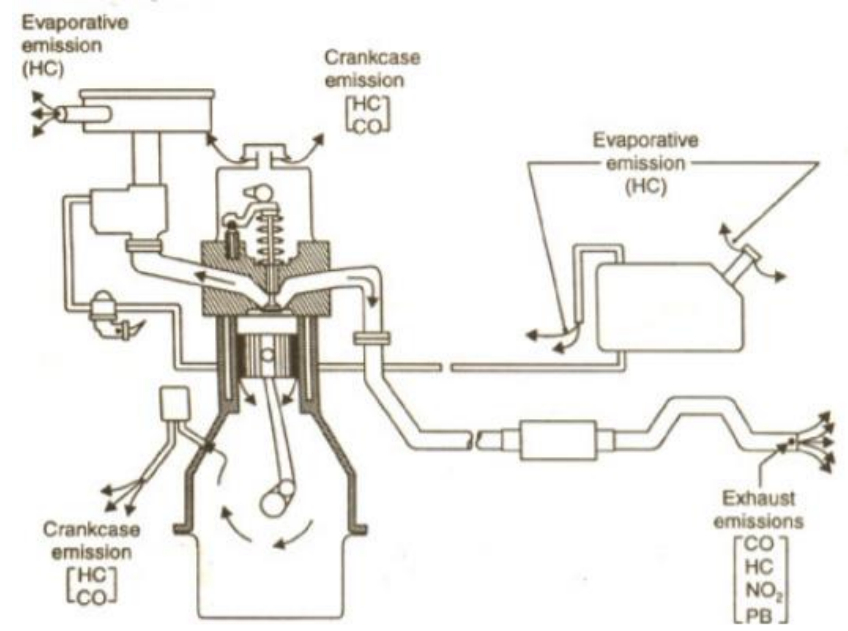

Figure 3. Emission types [19].

It has been well established by Sigworth and Payne that incompletely burned exhaust gases and crankcase fumes are major contributors to carburetor gumming, particularly in certain geographical locations. Their effects, while important, have little influence on portions of the intake system other than the carburetor. The extent to which these materials deposit is influenced somewhat by gasoline composition and additives; however, the gasoline itself does not directly contribute to this phase of the problem [21].

\subsubsection{Preformed gums}

Concerning preformed depositing materials, there has been considerable controversy during the past few years concerning the significance of gum content as determined by the ASTM standard namely "ASTM Method D381, Test for Existent Gum in Fuels by Jet Evaporation" [20-22]. In the past, this measure of fuel quality had been generally accepted as a reliable indication of the tendencies of fuel to form intake deposits [23]. More recently, however, it has been recognized that factors other than ASTM gum contribute to induction system deposits [24]. Hence, it is possible for two types of gasoline having the same ASTM gum content to vary considerably in their deposit-forming characteristics [25]. Nevertheless, there is considerable evidence indicating that high-gum-content fuels cannot be tolerated [26]. The upper limit established for nowadays is $10 \mathrm{mg}$ per $100 \mathrm{ml}$ [27, 28]. More recent studies by the CRC using small-scale, auxiliary-type Ordnance engines support the previous findings regarding gum tolerance and the importance of preformed residues as measured by the ASTM gum test D381 [29].

\subsection{Effect of Commercial Antioxidants on Gasoline stability}

Fuels that have poor storage stability invariably from excessive high-temperature inductionsystem deposits. On the other hand, some fuels which have satisfactory storage stability also form excessive induction-system deposits. This indicates that factors other than those affecting storage stability can be involved in stability at high-temperature induction system conditions. Furthermore, the data indicate that the type and concentration of the antioxidant, two of the major factors influencing storage stability, do not necessarily control high-temperature induction system deposits. Three fuels of different stability levels were tested to evaluate the effect of commercial antioxidants for control of intakevalve deposits. The results showed that the induction period indicated that base fuel $\mathrm{A}$ was 
very unstable and showed poor induction-period, response to $25 \mathrm{lb}$ per $1000 \mathrm{bbl}$ of a commercial antioxidant. The baffled-tube deposit was 91,3 $\mathrm{mg}$, indicating that high-intake valve moderate induction-period response to antioxidant additions. The baffled-tube deposit was $495 \mathrm{mg}$. Base fuel $\mathrm{C}$ was stable, showed a high inductionperiod response to antioxidants, and baffled-tube deposits were low. Each of the base fuels produced very low pentane-insoluble manifold deposits.

\subsection{Possible effects of current research on future methods and specifications due to gasoline stability}

Concerning the future of Methods D 525 and D 873 , it seems reasonable to expect them to be in use for some years to come $[24,26]$. The most probable effect of the research in progress is likely to be the application of a short series of composition coefficients in a regression equation in which induction period or gum time (or some modification of them) is the experimentally determined variable [29]. This suggestion implies the development of analytical methods of sufficient precision to determine the concentrations of pertinent components so that suitable coefficients may be used, although some of the coefficients will be for added materials the concentration of which is known at least to the producer [30-33]. It seems probable that such a system will be cumbersome and will therefore only be used under special circumstances, as, for example, to control the manufacture and purchase of motor fuel which will be subject to severe storage conditions [34-38]. Of course, the analytical requirements may not prove too burdensome for routine use, either because of improved methods or because only a few components will be of real significance. Specifications, of course, follow methods. Some organizations or groups must do a lot of work to determine the levels (as measured by such new methods) that will correspond to acceptable storage performance for a wide variety of fuels. The whole development will probably require at least ten years $[35,39,40]$.

Modern commercial gasoline has changed markedly since the early 1950's when the CRC desert storage work was carried out. The first commercial platinum catalytic reformer started up in late 1949, and since that time catalytic reforming capacity has increased rapidly to the present level of approximately 2,000,000 bbl per day [34, 41-43].

The hydrogen available from these reformers has been used to advantage in hydrogen-treating cracked stocks for reformer feed or simply for stability and removal of sulfur and nitrogen [44]. This trend has been pressured mainly by increasing octane requirements of modern automobiles, and to some extent by air pollution control regulations in certain metropolitan areas [45-48].

The net result has been a general improvement in gasoline stability [26, 49]. This trend in increasing stability is expected to continue as research produces new refining processes. Hydrocracking, for example, can supplement or replace catalytic cracking and produces highly stable gasoline [50].

At present, the only ASTM tests available for stability prediction are the D 525 induction period and the D 873 accelerated gum methods [26, 51]. The D 381 air jet gum should, of course, be mentioned since it is part of Method D 873 and is the factor that ostensibly correlates gasoline quality with expected performance in the engine $[26,51,52]$.

Test Methods D 525 and D 873 are both runs at unrealistically high temperatures $(212$ F) compared to field conditions under which gasoline is stored [24, 26, 49, 52]. The preferable induction system deposit (ISD) gum ratings on fuels stored at $110 \mathrm{~F}$ as a much better, although more time-consuming, method of predicting gum stability [24, 33, 53]. Another criticism that can be made [54] against Method D 525 is that it favors antioxidants that are effective under the D 525 test conditions but which are not necessarily the best stabilizing agents for types of gasoline under actual processing and storage conditions $[52,55]$.

Method D 525, therefore, tends to overlook the hindered phenols as antioxidants, whereas based on actual storage stability data found some of them very effective $[40,54,56]$. Proper use of hindered phenol antioxidants, even though they do not show up so well by older standards, has been, it is clear, a major factor in the generally improved storage stability of commercial gasoline in the last ten years $[54,56,57]$.

\section{CONCLUSIONS}

Concerning the current research work on gasoline gum stability, it is quite impressed by the work 
being done at the Bureau of Mines with tritiated hydrocarbons. It is a technique which should see an increasing application of this over-all problem. It is done, however, share some of the concern which surrounds the conflicting data on the contribution of aromatics to the gum. This conflict centers around the fact that some data. Show alkylbenzenes as major gum contributors and other data show increased stability in gasoline of increasing aromatic content.

According to the Bureau of Mines report, alkylbenzenes are the major contributors to total vapor transfer gum. The same report shows, however, that based on air-jet gum cyclo-olefins are first in order of contribution and alkylbenzenes are second. As the author suggests, the high aromatic content in this gum probably results from excessively severe storage. Another contributing explanation might be that the vapor transfer technique tends to leave some highboiling aromatics in the residue.

Vapor transfer gum is reported to be several times greater than the Method D 381 air jet gum. Data further show that ISD gum and engine gum, from either laboratory or passenger car engines, is generally less than D 381 gum. With such differences in gums, one cannot help but wonder how the data on the relative contributions of hydrocarbons to these various gums would look when using a normally aged gasoline rather than 1955 catalytically cracked stock. This cracked stock had an initial air-jet gum of $9.2 \mathrm{mg}$ per 100 $\mathrm{ml}$, which is higher than is considered acceptable for use in an engine. It is realized, of course, that it is difficult to do everything at once and it is heartily commended the Bureau of Mines on the work that it has done in the development of this tritium tracer technique.

Experiences with high aromatic content catalytic reformates have shown them to be quite stable. it has concurred with the author's finding that Method D 525 does not predict poor stability for them. Catalytic reformates show induction periods of $1500+$ min even without any added antioxidants. Method D 873 accelerated gums are low, less than $5 \mathrm{mg}$ per $100 \mathrm{ml}$ after $16 \mathrm{hr}$ aging with no inhibitor. It is also found very low ISD gums (1 to $2 \mathrm{mg}$ per liter) in leaded reformate stored with and without inhibitor for 8 weeks at $110 \mathrm{~F}$. Desert storage tests have shown reformatecontaining blends to be satisfactorily low in gum even after 2-yr storage. This good stability has been reflected in improved stability of finished types of gasoline. It is believed the complication of additives other than lead antiknock compounds and antioxidants should probably remain in the background until the behavior of base gasoline can be satisfactorily predicted. Once current research has developed and screened some promising techniques, it would seem reasonable for the related Technical Committee of ASTM to set up a cooperative test program to evaluate them on as many different fuels and engines as possible. Although it is agreed with the author that the development of a final ASTM method will require on the order of ten years, it is hoped that a usable method will be available in somewhat less time. The question of tetraethyllead and other additives in work being carried out at the Bureau has been frequently brought up these be kept in the background until it is known somewhat more about the behavior of the base gasoline itself.

When talking about alkylbenzenes and aromatics, it is important to keep in mind the fact that these are generic terms and that speaking of the aromatic content of gasoline as a whole may be rather misleading when it is being thought of problems having to do with the behavior of what may be a very minor proportion of the aromatics that are present. The principal purpose in presenting this information is to suggest that present-day gasoline may not have as large a margin instability as many of us may have been thinking. It is hoped to utilize these studies with the "synthetic gasoline" to determine some of the interreactions between the compounds. To date, it is used only one tagged compound in each stored sample of the catalytically cracked gasoline and it is known that it is reacting but we do not know with what it is reacting. The hope that by the use of this "synthetic" blend it can be learned some of the answers to the types of reactions that are occurring and the compounds that are reacting. 1

1

\section{ACKNOWLEDGMENTS}

Thanks for the people who had handled about the establishing fuel-oil laboratory called Inonu-Pal with me between 2007-2009 till it accredited. Thanks Rob Visser (Institute for Interlaboratory Studies, Manager in SGS Nederland B.V.), and Ing. Ronald Starink (Institute for Interlaboratory Studies Program Coordinator in SGS Nederland B.V.) for good cooperations and kindly understand as well as communicate with e-mail during accreditation. 


\section{REFERENCES}

[1] F. Pradelle, S. Leal Braga, Fonseca de A. R. Aguiar Martins, F. Turkovics, R. Nohra Chaar Pradelle, "Certainties and challenges in modeling unwashed and washed gums formation in Brazilian gasoline-ethanol blends," Chemical Engineering Research and Design, vol. 122, pp. 77-96, 2017.

[2] T. K. Garrett, K. Newton, W. Steeds, "Chapter 13 - Induction manifold design," In: T. K. Garrett, K. Newton, W. Steeds, editors. Motor Vehicle (Thirteenth Edition). Oxford: Butterworth Heinemann, pp. 479-515, 2000.

[3] F. Zhao, M. C. Lai, D. L. Harrington, "Automotive Spark-Ignited DirectInjection Gasoline Engines," Elsevier Science, 2000.

[4] R. N. Brady, "Internal Combustion (Gasoline and Diesel) Engines is. Reference Module in Earth Systems and Environmental Sciences," Elsevier, 2013.

[5] Z. Wang, X. Chen, J. Huang, L. Zheng, C. Peng, $\quad$ SSemi-free-jet simulated experimental investigation on a valveless pulse detonation engine," Applied Thermal Engineering, vol. 62, no. 2, pp. 407-414, 2014.

[6] J. Bennett, "7 - Advanced fuel additives for

modern internal combustion engines. In: R. Folkson, editor Alternative Fuels and Advanced Vehicle Technologies for Improved Environmental Performance, Woodhead Publishing, pp. 165-194, 2014.

[7] G. Hoffmann, G. M. Ramsay, W. F. Piock,

S. Schilling, "Outwardly opening solenoid injector for homogenous Gasoline engines with direct injection," In: ImechE, editor Fuel Systems for IC Engines. Woodhead Publishing, pp. 63-75, 2012.

[8] F. Yan, L. Xu, Y. Wang, "Application of hydrogen enriched natural gas in spark ignition IC engines: from fundamental fuel properties to engine performances and emissions," Renewable and Sustainable Energy Reviews, vol. 82, pp. 1457-1488, 2018.

[9] A. Agarwal, A. Singh, R. Maurya. "Evolution, challenges and path forward for low temperature combustion engines,"
Progress in Energy and Combustion Science, vol. 61, pp. 1-56, 2017.

[10] W. J. D. Annand, "Chapter Two Gasoline

Engines," In: C. Arcoumanis, editor, Internal Combustion Engines. Academic Press, pp. 31-99, 1988.

[11] K. Gradon, S. C. Miller, "Combustion development on the rolls-royce sprey engine" In: I. E. Smith, editor, Combustion

in Advanced Gas Turbine Systems, Pergamon, pp. 45-76, 1968.

[12] S. Verhelst, T. Wallner, "Hydrogen-fueled internal combustion engines," Progress in Energy and Combustion Science, vol. 35, no. 6, pp. 490-527, 2009.

[13] F. K. Sully, "Chapter 7 - Engine components," In: F. K. Sully, editor, Motor Vehicle Mechanic's Textbook (Fifth Edition), Butterworth Heinemann, pp. 89109, 1988.

[14] R. K. Gogola, "Electronic Control of Fuel Mixture Preparation and Injection in Internal Combustion Engines," American Journal of Mechanical Engineering, vol. 2, no. 7, pp. 231-238, 2014.

[15] G. Guinther, S. Smith, "Formation of Intake Valve Deposits in Gasoline Direct Injection Engines," SAE International Journal of Fuels and Lubricants vol, 9, 2016.

[16] C. Koyunoğlu, "New advancements in fuels and lubricants for the aerospace industry," Hiperlink, 2019.

[17] C. Cole, "Is Carbon Buildup a Problem With Direct-Injection Engines?" Available from: https://www.autoguide.com/autonews/2015/01/is-carbon-buildup-aproblem-with-direct-injection-engines.html.2016.

[18] Anonym. Star Tron Enzyme Fuel Treatment - Concentrated Gas Formula, 2018. Available from: http://www.starbrite.com/item/star-trongasoline-fuel-additive. 2017.

[19] K. Abouemara, S. Fikry, "Emission Control Technologies in Spark Ignition Engines," Journal of Student Research, vol 9, no. 1, 2020.

[20] C. Kalamaras, K. Shaik, G. Kalghatgi, H. Babiker, A. Alsamah, D. McLeary, "SuperButolTM - A novel high-octane 
gasoline blending component," Fuel, vol 195, pp. 165-173, 2017.

[21] N. I. Tracy, D. W. Crunkleton, G. L. Price, "Gasoline production from phytol," Fuel, vol. 89, no. 11, pp. 3493-3497, 2010.

[22] K. E. Dahlin, S. R. Daniel, J. H. Worstell, "Deposit formation in liquid fuels. 1. Effect of coal derived Lewis bases on storage stability of Jet A turbine fuel," Fuel vol 60, no 6, pp. 477-480, 1981.

[23] J. H. Worstell, S. R. Daniel, "Deposit formation in liquid fuels. 2. The effect of selected compounds on the storage stability of Jet A turbine fuel," Fuel, vol 60, no. 6, pp. 481-484, 1981.

[24] J. M. Nagpal, G. C. Joshi, S. N. Rastogi, "Stability of cracked naphthas from thermal and catalytic processes and their additive response. Part I. Evaluation of stability and additive response," Fuel, vol 74, no. 5, pp. 714-719, 1995.

[25] J. M. Nagpal, G. C. Joshi, S. N. Rastogi, "Stability of cracked naphthas from thermal and catalytic processes and their additive response. Part II. Composition and effect of olefinic structures. Fuel, vol 74, no. 5, pp. 720-724, 1995.

[26] R. C. C. Pereira, V. M. D. Pasa, "Effect of mono olefins and diolefins on the stability of automotive gasoline," Fuel, vol 85, no. 12, pp. 1860-1865, 2006.

[27] R. L. McCormick, M. Ratcliff, L. Moens, R. Lawrence. "Several factors affecting the stability of biodiesel in standard accelerated tests," Fuel Processing Technology, vol 88, no. 7, pp. 651-657, 2017.

[28] G. W. Mushrush, E. J. Beal, D. R. Hardy, J. M. Hughes. "Nitrogen compound distribution in middle distillate fuels derived from petroleum, oil shale, and tar sand sources," Fuel Processing Technology, vol 61, no. 3, pp. 197-210, 1999.

[29] Y. Zvirin, M. Gutman, L. Tartakovsky, "Chapter 16 - Fuel Effects on Emissions," In: E. Sher, editor, Handbook of Air Pollution From Internal Combustion Engines, San Diego, Academic Press, pp. 547-651, 1998.

[30] M. Meira, C. M. Quintella, H. R. G. Tanajura da Silva, J. D. E. S. Fernando JDES, P. R. da Costa Neto,
"Determination of the oxidation stability of biodiesel and oils by spectrofluorimetry and multivariate calibration," Talanta, vol 85, no. 1, pp. 430-434, 2011.

[31] A. C. Roveda, M. Comin, A. R. L. Caires, V. S. Ferreira, M. A. G. Trindade, "Thermal stability enhancement of biodiesel induced by a synergistic effect between conventional antioxidants and an alternative additive," Energy vol. 109, pp. 260-265, 2016.

[32] J. Pullen, K. Saeed, "An overview of biodiesel oxidation stability," Renewable and Sustainable Energy Reviews, vol. 16, no. 8, pp. 5924-5950, 2012.

[33] J. Van Gerpen, G. Knothe, "16 Bioenergy

and Biofuels from Soybeans" In: L. A. Johnson, P. J. White, R. Galloway, editors. Soybeans, AOCS Press, pp. 499538, 2008.

[34] D. L. Klass, "Chapter 11 - Synthetic Oxygenated Liquid Fuels," In: D. L. Klass, editor, Biomass for Renewable Energy, Fuels, and Chemicals, San Diego: Academic Press, pp. 383-443, 1998.

[35] A. Carrero, A. Pérez, "5 - Advances in biodiesel quality control, characterisation and standards development," In: R. Luque, J. A. Melero, editors, Advances in Biodiesel Production, Woodhead Publishing, pp. 91-130, 2012.

[36] G. Knothe, "6 - Fuel Properties," In: G. Knothe, J. Krahl, J. Van Gerpen, editors, The Biodiesel Handbook (Second Edition), AOCS Press, pp. 137-251, 2010.

[37] J. G. Speight, "Chapter 3 - Refining Chemistry," In: J. G. Speight, editor, The Refinery of the Future. Boston: William Andrew Publishing, pp. 81-116, 2011.

[38] J. C. J. Bart, N. Palmeri, S. Cavallaro, "14 -Sustainability and use of biodiesel," In: J. C. J. Bart, N. Palmeri, S. Cavallaro, editors, Biodiesel Science and Technology, Woodhead Publishing, pp. 625-712, 2010.

[39] S. C. Bhatia, "21 - Ethanol. In: S. C. Bhatia,

editor, Advanced Renewable Energy Systems, Woodhead Publishing India, pp. 523-573, 2014.

[40] J. C. J. Bart, N. Palmeri, S. Cavallaro, "12 - Analytical methods and standards for quality assurance in biodiesel production," 
In: J. C. J. Bart, N. Palmeri, S. Cavallaro, editors, Biodiesel Science and Technology, Woodhead Publishing, 2010, pp. 514-570.

[41] P. Karjalainen, L. Pirjola, J. Heikkilä, T. Lähde, T. Tzamkiozis, L. Ntziachristos, "Exhaust particles of modern gasoline vehicles: A laboratory and an on-road study," Atmospheric Environment, vol 97, pp. 262-270, 2014.

[42] B. D. Solomon, K. Krishna, "The coming sustainable energy transition: History, strategies, and outlook," Energy Policy, vol 39, no. 11, pp. 7422-7431, 2011.

[43] L. D. Claxton, "The history, genotoxicity, and carcinogenicity of carbon-based fuels and their emissions. Part 3: Diesel and gasoline," Mutation Research/Reviews in Mutation Research, vol. 763, pp. 30-85, 2015.

[44] J. Worstell, "Chapter 1 - Introduction," In: J. Worstell, editor, Scaling Chemical Processes. Butterworth-Heinemann, pp. 1-15, 2016.

[45] C. Arcoumanis, "Internal Combustion Engines," Elsevier Science, 2012.

[46] M. Bedon, M. Milosavljevic, V. Morel, J. P. Solari, G. Bourhis, R. Dauphin, "Design of a valuable fuel couple and engine compression ratio for an OctaneOn-Demand SI engine concept: A simulation approach using experimental data," Fuel, vol. 189, pp.107-119, 2017.

[47] R. Stradling, J. Williams, H. Hamje, D. Rickeard. "Effect of Octane on Performance, Energy Consumption and Emissions of Two Euro 4 Passenger Cars," Transportation Research Procedia, vol. 14, pp. 3159-3168, 2016.

[48] D. E. Stikkers, "Octane and the environment," Science of The Total Environment, vol. 299, no. 1, pp. 37-56, 2002.

[49] W. R. Gilbert, "Effect of FCC variables on the formation of gasoline gum precursors," In: M. Occelli, editor,
"Studies in Surface Science and Catalysis," Elsevier, pp. 247-256, 2004.

[50] T.V. Malleswara Rao, X. Dupain, M. Makkee, "Fluid catalytic cracking: Processing opportunities for FischerTropsch waxes and vegetable oils to produce transportation fuels and light olefins," Microporous and Mesoporous Materials, vol 164, pp. 148-163, 2012.

[51] H. A. Dabbagh, F. Ghobadi, M. R. Ehsani, M. Moradmand, "The influence of ester additives on the properties of gasoline," Fuel, vol. 104, pp. 216-223, 2013.

[52] T. N. Castro Dantas, M. S: G. Dantas, A. A. Dantas Neto, C. V. D'Ornellas, L. R. Queiroz LR. "Novel antioxidants from cashew nut shell liquid applied to gasoline stabilization," Fuel, vol. 82, no. 12, pp. 1465-1469, 2003.

[53] F. S. Forbes, P. A. Van Splinter, "Liquid Rocket Propellants," In: R. A. Meyers, editor, Encyclopedia of Physical Science and Technology (Third Edition), New York: Academic Press, pp. 741-747, 2003.

[54] J. Wang, M. Thomson, T, Connolly, A. Z. Tong, "Development of an analytical method for determining hindered phenolic antioxidants in exhaust emissions from light-duty vehicles," Atmospheric Pollution Research, vol. 7, no. 2, pp. 326-332, 2016.

[55] M. Hernandez, L. Menchaca, A. Mendoza A, "Fuel economy and emissions of lightduty vehicles fueled with ethanolgasoline blends in a Mexican City," Renewable Energy, vol. 72, pp. 236-242, 2014.

[56] W. W. Focke, I. Westhuizen, X. Oosthuysen, "Biodiesel oxidative stability from Rancimat data," Thermochimica Acta, vol. 633, pp. 116-121, 2016.

[57] J. Pospisil, "Hindered phenolic antioxidants," Additives for Polymers, vol. 1994, no. 4, p. 5. 